\title{
CIGÁNYZENÉSZEK KORABELI DOKUMENTUMOKBAN, AVAGY NEMZETELLENES-E A JAZZ?
}

A Gondolat Kiadó gondozásában és Hajnáczky Tamás szerkesztésében jelent meg az a dokumentumgyüjtemény, amely a két világháború között élő és dolgozó, gyakran a mindennapi megélhetésükért küzdő muzsikus cigányok törekvéseit mutatja be, korabeli források segítségével. A könyv rövid előszó után egy bevezető tanulmányban mutatja be az összegyüjtött írásokat, majd hat tematikus egységre tagolva következnek maguk a dokumentumok, végül a rövidítések jegyzéke és névmutató zárja a terjedelmes, több mint háromszázötven oldalas kötetet.

A cigányokkal kapcsolatos kérdések is olyanok Magyarországon, mint a foci: mindenki ért hozzá, de keveset tud róla. Különösen így van ez a cigányzenészekkel kapcsolatban, akikkel az elmúlt évszázadokban az emberek jelentős részének volt és van kapcsolata, hiszen az említett romák foglalkozása régóta a társadalomban meglévő szórakoztató funkciók egyikét jelenti, és napjainkban is erős a jelenlétük ezen a területen. Pozitív, de létező elöítélet szerint „,a cigányoknak a vérükben van a zene", amely miatt tulajdonképpen minden roma ember képes a muzsikálásra, sőt, valószínüleg hegedűvel a hónuk alatt születnek. Ez, sajnálatos módon azonban nem igaz. A különböző, egymástól jelentős mértékben, történeti múltjukban, anyanyelvükben, szokásrendszerükben és kulturális hagyományaikban is eltérő csoportok (mert hát nincsenek is olyanok, hogy „,cigányok”, de ez egy másik történet) közül az úgynevezett „,romungrok”, azaz „,magyarcigányok" közül kerülnek ki azok a zenéléssel foglalkozó roma emberek, akiket mi „cigányzenészeknek” nevezünk. Abból a csoportból, amelynek tagjai a legrégebben élnek Magyarországon, és a 19. század második felében és a 20. század első felében már olyan mértékben nemcsak integrálódtak, de asszimilálódtak is a magyar társadalomba, hogy az általuk játszott zenei stílus, a verbunkosból kinőtt „magyar nóta”, azaz cigányzene, nem cigány népzenét jelent, hanem a magyar kultúra szerves részét képező, müdalokra épülő hagyományt. Ezt a csoportot, ezeket az embereket mindenki ismerni véli, hiszen néhány évtizede még nagyon sok vendéglátóipari egységben találkozhattunk úgynevezett cigányzenekarral és az általuk játszott repertoárral. A kérdés tudományos igényü feldolgozása azonban nagy hiányosságokat mutat, és nemcsak napjaink vonatkozásában, hanem szinte az elmúlt két évszázad tekintetében. A téma szintetizáló igényű, nagyobb feldolgozása az 1970-es években jelent meg utoljára, Sárosi Bálint tollából. Így igencsak örvendetes minden olyan adalék, ami hozzátesz valamit a történethez. A most megjelent, Hajnáczky által szerkesztett kötet ugyan nem törekszik nagy összegzés létrehozására, de rendkívüli értéke, hogy olyan, lassan már feledésbe 
merült dokumentumokat tár az érdeklődők elé, amelyek segíthetnek a kérdés árnyaltabb megközelítésében.

Rendhagyó módon kezdjük a kötet bemutatását annak második felével, a dokumentumokkal. Hat tematikus egységbe, azaz hat fejezetbe szervezve közli a szerkesztő az anyagokat. A források alapvetően két nagyobb csoportra oszthatók: egyrészt megtalálhatóak közöttük rendeletek, közgyülési ülések jegyzőkönyvei, azaz úgynevezett „hivatalos iratok” is, de döntő többségében újságcikkek alkotják a nyolcvanegy dokumentumot. Itt kell azt is megjegyeznünk, hogy sajnálatos módon nincs a kötetben a dokumentumoknak külön jegyzéke, listaszerü felsorolása, legfeljebb csak a bevezető tanulmány végén, a bibliográfiában találunk egy, nem teljesnek tünő lajstromot.

Az első és egyben legnagyobb, leginkább összetett tematikus egység a Harc címet viseli. Ebben a fejezetben harminchárom újságcikk segítségével a cigányzenészek egy nem körülhatárolható nagyságú csoportjának mindennapi küzdelmeivel ismerkedhetünk meg. Értesülünk a megjelenő, általuk jazznak nevezett új zenei stílus miatti háttérbe szorulásukról, a külföldi vendéglátóhelyeken történő mellözöttségükről, a Magyar Rádióval kiélesedett vitáról a fellépti díjak vonatkozásában, de leginkább arról a törekvésröl, hogy a problémák megoldását az államtól, a politikai vezetéstől várják. A következő, Közgyülések fejezetben nyolc korabeli dokumentum segítségével a Cigányzenészek Országos Egyesületében és később más szervezetekben történteket, valamint a Belügyminisztérium és egyéb hivatalos szervek cigányzenészek müködésével kapcsolatos rendelkezéseit ismerhetjük meg. Az ezt követő „Közgyülések” rész az említett szervezet közgyűléseiről készült jegyzőkönyveket tartalmazza, a Zeneiskola fejezet pedig az úgynevezett Bihari Zeneiskola alapításával és müködésének körülményeivel kapcsolatban közöl nyolc dokumentumot a Magyar Cigányzenészek Lapja hasábjairól. Az utolsó két fejezetben, először a „Nótaünnep” címü részben az 1930-ban, a Bihari Zeneiskola fenntartása érdekében megszervezett hangversenyröl és az azt követő elszámolási vitákról értesülhetünk, míg az utolsó részben, a „Jubileum” cím alatt arról a Zsigmond király által, László vajdának szóló oklevél (amelyet azóta a tudomány nem tekint valósnak) kiadásának ötszáz éves évfordulója tiszteletére rendezett ünneplés terveiről tudósítanak, amely egyszersmind a romák félévezredes letelepülésének évfordulójáról kívánt megemlékezni.

A forrásokat tanulmányozva két szempontot ajánlunk az olvasók figyelmébe. Egyrészt elmondható, hogy fontos dokumentumokról van szó, hiszen olyan részleteket is megtudunk a korabeli cigányzenészek társadalmi helyzetéröl, anyagi viszonyairól, gondolkodásmódjáról, amelyeket más források hiányában nehéz lenne rekonstruálni. De ha figyelmesen olvassuk a részleteket, rájövünk arra is, hogy milyen fontos képet, benyomást szerzünk az adott kor, a két világháború közti időszakban a magyar társadalom tagjainak gondolkodásáról, a korszak szellemiségéről is. Érzékelhetjük, hogy milyen módon és mértékben van jelen az első világ- 
háborút követő trauma a társadalomban, valamint benyomásokat szerezhetünk a társadalomban mindig jelen lévő „felvilágosult abszolutista gondolkodás” soha el nem múló igényéröl, amely szerint a megoldásokat nem mi magunk keressük, nem teszünk erőfeszítéseket, nem a modernizációban látjuk a nehéz helyzetből kivezető utat, hanem kényelmesen hátradőlve, az államtól, a politikai vezetéstől reméljük minden gondunk megoldását. Persze hiba lenne azt gondolni, hogy ez a magatartás mindenkire, így a cigányzenészek összességére is vonatkozik, hiszen máshonnan, más kutatásokból tudjuk, hogyan és milyen mértékben jelentek meg a roma muzsikusok körében éppen ebben az időszakban az ,átlépők", azaz a stílusváltók. Napjaink zenei világában is jól látható, milyen mértékben van jelen a komolyzenétôl a lakodalmas szórakoztatásig a mára már átértelmezett és megváltozott jelentésü 'cigányzenész' fogalma.

Ez utóbbi miatt érdemes felhívni a figyelmet a másik szempontra is, ez pedig az alapos forráskritika, amivel a közölt részleteket olvasni érdemes. Mivel a források jelentős része a korabeli sajtóból, köztük jelentős mértékben bulvárlapokból származik, érdemes mindig fenntartásokkal kezelni az állításokat - különös tekintettel az irodalmi stílusban megírt riportok és interjúk esetében - és összevetni más forrásértékü közlésekkel is. Vonatkozik ez a Magyar Cigányzenészek Lapjára is, mert bár sok olyan információt tartalmaz, amely egyébként nehezen érhető el, de végül is egy meghatározott érdekcsoport szócsöve volt, így érdemes óvatos lenni a megfogalmazott állításokkal.

Végül ejtsünk néhány szót a bevezető tanulmányról is, amely alapvetően a felsorolt dokumentumok mélyebb elemzés nélküli bemutatását valósítja meg. Ez a rész inkább egyfajta összefoglalás azok számára, akik nem feltétlenül kívánják átrágni magukat a közölt dokumentumok mindegyikén.

Összességében elmondható, hogy nagyon fontos kötet jelent meg, olyan dokumentumokkal, amelyek egyébként már nehezen elérhetőek a téma iránt érdeklödők számára. Ebben a könyvben a fiatal Hajnáczky erőssége a kitartó munkában, a szisztematikusan összegyüjtött, rendezett dokumentumok közlésében nyilvánul meg, és ez bizony nem kevés, sőt. Ez pedig nagyon fontos mindazon ellustult és öregedő kutatók számára, akik nagyobb, összegző munka megírásának szándékával ülnek le számítógépük elé.

(Hajnáczky Tamás szerkesztő: Magyar Cigányzenészek Egyesülete. Cigányzenészek harca a két világháború közötti Magyarországon. Budapest: Gondolat Kiadó, 2019, 354 o.)

Kállai Ernő

föiskolai tanár Eszterházy Károly Főiskola 